\title{
Myelosuppressive Therapy
}

National Cancer Institute

\section{Source}

National Cancer Institute. Myelosuppressive Therapy. NCI Thesaurus. Code C15690.

Any treatment that decreases the rate of blood cell production in the bone marrow. 